\title{
EFFICIENCY OF BIOLOGICAL PREPARATIONS AND MICROELEMENTS USE IN THE SPRING WHEAT GROWING TECHNOLOGY \\ ${ }^{1}$ Derevyansky V. P., ${ }^{1}$ Vlasyuk O. S., ${ }^{2}$ Malinovskaya G. M.
}

\author{
${ }^{1}$ Khmelnitskiy State Agricultural Experimental Station, Institute of Forage and \\ Agriculture of Podillya, NAAS \\ ${ }^{2}$ Institute of Agriculture, NAAS \\ 1, Samchyky str., Samchyky, Starokonstyantynivsky district \\ Khmelnytskyy region, 31182, Ukraine \\ e-mail: vchsekretar-hdsgds@yandex.ru
}

The paper presents the results of the efficiency study of seed treatment and foliar spraying of spring wheat crops with biopreparations and complex of microelements was studied. Compositions with the ability to reduce the spread of diseases, increase crop productivity and improve grain quality were selected.

Key words: spring wheat, inoculation, microelements.

In conditions of poor resource supply of agriculture and environmental crisis phenomena, there is an urgent need to develop technological solutions that would improve possibilities of natural processes that influence plant growth and development, provide stability to agricultural systems, reduce chemical load on agrocenosis while increasing productivity potential of crops. Use of biological preparations of new generation is one of the solutions that have integrated positive impact on the development of plant-bacterial associations and nitrogen fixation processes, mobilization of phosphorous and contribute to the formation of plant resistance to the diseases [1-3]. In this regard, the urgency of selection and use of biological methods for intensifying crop production process is clear.

The aim of our research was to study the impact of complex treatment with microbial preparations of seeds and crops and productivity of spring wheat at cultivation in forest-steppe zone of Western Ukraine.

Materials and methods. The study was performed in field experiments in 20062008 in temporary crop rotation in Khmelnitskiy State Agricultural Experimental Station, NAAS. In addition to biological factors the influence of herbicides alone and together with biological prepartions on the productive potential of spring was examined.

The scheme of the experiment:

I. Factor "A" - weed control:

1. Soil herbicide Racer 2.01 / ha with presowing cultivation;

2. Post emergent herbicide Dialen Super $0.71 /$ ha.

II. Factor "B" - pre-sowing seeds bacterization:

1. Without treatment (control);

2. Agrobacterium radiobacter.

III. Factor "C" - foliar application:

1. Without application (control); 


\section{Hetomik;}

3. Ecolyst for grain crops;

4. Hetomik + Ecolyst for grain crops.

The total research area was $100 \mathrm{~m}^{2}$, accountable $-72 \mathrm{~m}^{2}$. Three experimental replications, systematic plots placement. Variety of spring wheat used in the experiments - Collectyvna 3.

Research was performed on black ashed middle clay loam low truncated soils. Agrochemical characteristics of the arable topsoil layer: $\mathrm{pH}_{\text {salt }}-5.5-6.0$; humus content (by Tyurin) - 3.2-3.6; easy hydrolysable nitrogen $-12-17 \mathrm{mg} / 100 \mathrm{~g}$; mobile phosphorus $13-18.5 \mathrm{mg} / 100 \mathrm{~g}$; exchangeable potassium - 10.0-11.1 mg/100 g soil.

Spring wheat sowing was carried out in field crop rotation. Pre crop - sugar beets. Farming technologies - common practice for Western Forest Steppe region. Tillage: stubble disking after sugar beet harvesting followed with plowing and layering of surface. Mulching was performed in early spring. Fertilizers were applied at the $\mathrm{N}_{32} \mathrm{P}_{32} \mathrm{~K}_{32}$ rate prior to the seeding. Seeding rate -6 million of seeds per 1 ha.

Seeds and crops were treated in accordance to the scheme of experiment. Agrobacterium radiobacter (strain number 10) provided by ASRIAM, St. Petersburg, Russia) was used for seeds bacterization. The total bacterial load was 200 thousand cells per seed.

Hetomik - preparation with micromycete agent Chaetomium cochliodes 3250, with high antagonistic activity to a wide range of pathogenic fungi (originator - Institute for Agricultural Microbiology and AgrOIndustrial production NAAS). Used application rate $200 \mathrm{~g} / \mathrm{ha}$ [4].

Ecolyst for grain crops - chelated set of microelements (EDTA chelated). The preparation was used at recommended rate $-41 /$ ha.

The climatic and meteorological conditions in 2006-2010 were favorable for cultivation of spring wheat. The average air temperature during the growing season (May - September, 2006) was $18.5^{\circ} \mathrm{C}, 2007-18.7{ }^{\circ} \mathrm{C}, 2008-18.8^{\circ} \mathrm{C}, 2009-19.2^{\circ} \mathrm{C}, 2010-$ $19.6^{\circ} \mathrm{C}$. Total precipitation for May - September in 2006 - was $695 \mathrm{~mm}$, in $2007-769.4$ $\mathrm{mm}$, in $2008-655.6 \mathrm{~mm}$, in $2009-475 \mathrm{~mm}$, in $2010-976.6 \mathrm{~mm}$.

Recording and observations were performed using conventional methods $[5,6]$.

Results and discussion. Weather conditions during 2006 - 2010 growing seasons were favorable for the development and spread of diseases of spring wheat. Diseases observation on the development had showed a decrease in their development under the influence of complex treatment. Thus, the development of Septoria leaf blotch in variants with treatment of seeds and crops with microbial preparations and microelements (on the background of soil herbicide Racer) had decreased by $10.2-13.6 \%$ as compared to control. In other variants, the disease development was significantly higher.

In study of biological preparations on the development of root rots it was established that the lowest (7.3\%) spread of the disease was observed in variants with seeds treatment with Agrobacterium radiobacter (on the background of soil herbicides Racer), while the level of disease development in control plants was $12.1 \%$ (no seeds treatment). 
Weediness in the factor that reduces the productivity of spring wheat crops the most. In $2006-2010$ years the selectivity to spring wheat and phytotoxic effect on the weeds composition of soil herbicide Racer and post emergent herbicide Dialen Super was studied. Most clearly herbicidal activity of preparations and their application means is determined by measurement of weeds mass increase. Records performed prior to the harvest had showed that the use of soil herbicide Racer was similar to the action of post emergent herbicide.

In wet conditions of spring in 2007 and 2008 the herbicidal activity of soil preparation Racer had increased. Its use had reduced the total number of weeds in $93-$ 96\%. The herbicidal activity of Dialen Super against the dicot weeds was 92-95\%.

Measurement of stand density of spring wheat plants conducted at full seedling stage and before harvest had indicated that soil herbicide Racer (2.0 1/ ha) had not significantly reduced the crop stand quality. The post emergent herbicide characterized with high crops selectivity had also not affected the crop stand quality.

The performed structural analysis had showed that spring wheat plants had a greater height in variants with seeds and crops treated with microbial preparation and microelements, which was $85-101 \mathrm{~cm}$, while in control without treatments on the background of post emergent herbicide $-76.6 \mathrm{~cm}$.

Yield record in 2006 - 2010 had confirmed the efficiency of complex use of herbicides, microbial preparations and foliar treatments (Table 1).

Analysis of yield data had also showed that the treatment of seeds and crops with microbial preparation in combination with the Ecolyst foliar on the background of soil herbicide Racer was the most effective among the studied variants.

The quality of the grain was different depending on the preparation used and weather conditions of the year. Thus, the gluten content in spring wheat grain was higher in variants with seeds and crops treatment with Agrobacterium radiobacter + Khetomik + Ecolyst for grain crops on the background of Dialen Super $-25.6 \%$, while in control variant $(\mathrm{K} / 2)$, without any treatment except of herbicide - it was $24.2 \%$.

Using soil herbicide Racer (2.0 1/ha) + seed treatment with Agrobacterium radiobacter and Khetomik for seeds treatment and foliar application of Ecolyst in technology of spring wheat growing can increase the yield by $5.0 \mathrm{c} /$ ha or by $14.1 \%$. This reduces the production costs, and increase the profit per $1 \mathrm{~kg}$ product and its profitability.

As indicated by the results of our study seeds inoculation with microbial preparations combined with crop treatment with Khetomik followed by foliar application of microelements can reduce the infection of spring wheat crops with root rots and Septoria leaf blotch. Complex treatment of seeds and vegetating plants with microbial preparation and microelements had stimulated the vegetative and generative development of plants, had increased the gluten content in grain of spring wheat and had increased the crop productivity by $15-19 \%$.

Energy costs for herbicides, microelements and preparation applications make up $20-22 \%$ of the total costs for crops growing, but due to increase in productivity they will be compensated in 5-6 times. 
Table 1. Effect of herbicides and biological preparation on yield of spring wheat (2006-2010 years).

\begin{tabular}{|c|c|c|c|c|c|c|c|c|}
\hline \multirow{3}{*}{ Variants } & \multicolumn{6}{|c|}{ Урожайність, ц/га } & \multirow{2}{*}{\multicolumn{2}{|c|}{$\begin{array}{l}\text { Increment } \\
\text { to control }\end{array}$}} \\
\hline & \multirow{2}{*}{2006} & \multirow{2}{*}{2007} & \multirow{2}{*}{2008} & \multirow{2}{*}{2009} & \multirow{2}{*}{2010} & \multirow{2}{*}{ Average } & & \\
\hline & & & & & & & $\mathrm{c} / \mathrm{ha}$ & $\%$ \\
\hline $\begin{array}{l}\text { Background 1. Application of soil } \\
\text { herbicide Racer }\end{array}$ & 34,2 & 21,4 & 35,8 & 32,6 & 30,4 & 30,9 & - & - \\
\hline $\begin{array}{l}\text { Background I + seeds treatment } \\
\text { with Agrobacterium radiobacter }\end{array}$ & 38,2 & 23,9 & 37,6 & 33,5 & 31,9 & 33,0 & 2,1 & 6,4 \\
\hline $\begin{array}{l}\text { Background I + crop treatment } \\
\text { with Khetomic }\end{array}$ & 36,3 & 22,8 & 36,4 & 32,9 & 31,3 & 31,9 & 1,0 & 3,1 \\
\hline $\begin{array}{l}\text { Background I + seed treatment } \\
\text { with Agrobacterium radiobacter }+ \\
\text { crop treatment with Khetomik }\end{array}$ & 39,8 & 24,8 & 39,2 & 37,9 & 33,5 & 35,0 & 4,1 & 11,7 \\
\hline $\begin{array}{l}\text { Background I + crop treatment } \\
\text { with Ecolyst for grain crops }\end{array}$ & 36,2 & 22,7 & 38,4 & 33,3 & 31,8 & 32,5 & 1,6 & 4,9 \\
\hline $\begin{array}{l}\text { Background I + seed treatment } \\
\text { with Agrobacterium radiobacter }+ \\
\text { crop treatment with Ecolyst for } \\
\text { grain crops }\end{array}$ & 38,4 & 22,9 & 39,1 & 34,4 & 32,5 & 33,5 & 2,6 & 7,8 \\
\hline $\begin{array}{l}\text { Background I + crops treatment } \\
\text { with Khetomik and Ecolyst for } \\
\text { grain crops }\end{array}$ & 37,4 & 23,6 & 39,7 & 33,0 & 32,7 & 33,3 & 2,4 & 7,2 \\
\hline $\begin{array}{l}\text { Background I + seeds treatment } \\
\text { with Agrobacterium radiobacter }+ \\
\text { crops treatment with Khetomik }+ \\
\text { Ecolyst for grain crops }\end{array}$ & 40,9 & 24,9 & 40,8 & 38,1 & 34,8 & 35,9 & 5,0 & 13,9 \\
\hline $\begin{array}{l}\text { Background 2. Application of post } \\
\text { emergent herbicide Dialen Super }\end{array}$ & 33,7 & 22,7 & 34,1 & 33,4 & 30,6 & 30,9 & 0 & 0 \\
\hline $\begin{array}{l}\text { Background } 2+\text { seeds treatment } \\
\text { with Agrobacterium radiobacter }\end{array}$ & 37,1 & 24,3 & 37,2 & 32,9 & 31,8 & 32,7 & 1,8 & 5,5 \\
\hline $\begin{array}{l}\text { Background } 2+\text { crop treatment } \\
\text { with Khetomik }\end{array}$ & 37,0 & 23,5 & 37,1 & 32,8 & 31,9 & 32,5 & 1,6 & 4,9 \\
\hline $\begin{array}{l}\text { Background } 2 \text { Agrobacterium } \\
\text { radiobacter }+ \text { crop treatment with } \\
\text { Khetomik }\end{array}$ & 37,2 & 25,9 & 38,0 & 36,0 & 33,3 & 34,1 & 3,2 & 9,4 \\
\hline $\begin{array}{l}\text { Background } 2+\text { crop treatment } \\
\text { with Ecolyst for grain crops }\end{array}$ & 36,0 & 22,5 & 37,6 & 34,0 & 31,7 & 32,3 & 1,4 & 4,3 \\
\hline $\begin{array}{l}\text { Background } 2+\text { seeds treatment } \\
\text { with Agrobacterium radiobacter }+ \\
\text { crop treatment with Ecolyst for } \\
\text { grain crops }\end{array}$ & 37,9 & 22,8 & 37,8 & 37,3 & 33,7 & 33,9 & 3,0 & 8,8 \\
\hline $\begin{array}{l}\text { Background } 2+\text { crops treatment } \\
\text { with Khetomik }+ \text { Ecolyst for grain } \\
\text { crops }\end{array}$ & 35,7 & 25,1 & 38,2 & 34,4 & 32,7 & 33,2 & 2,3 & 6,9 \\
\hline $\begin{array}{l}\text { Background } 2+\text { seeds treatment } \\
\text { with Agrobacterium radiobacter }+ \\
\text { crops treatment with Khetomik } \\
\text { and Ecolyst for grain crops }\end{array}$ & 39,2 & 27,6 & 40,1 & 36,3 & 34,5 & 35,5 & 4,6 & 12,9 \\
\hline $\mathrm{LSD}_{0,5}: \quad \mathrm{A}-$ seeds treatment & 0,27 & 0,35 & 0,18 & 0,19 & 0,26 & & & \\
\hline $\mathrm{B}-$ crop treatment & 0.29 & 0,40 & 0,26 & 0,27 & 0.26 & & & \\
\hline $\mathrm{C}$ - interaction & 0,33 & 0,42 & 0,26 & 0,27 & 0,18 & & & \\
\hline $\mathrm{AB}-$ & 0,54 & 0,60 & 0,37 & 0,38 & 0,52 & & & \\
\hline $\mathrm{AC}-$ & 0,54 & 0,60 & 0,37 & 0,38 & 0,37 & & & \\
\hline $\mathrm{BC}-$ & 0,79 & 0,85 & 0,74 & 0,54 & 0,37 & & & \\
\hline $\mathrm{P}, \%$ & 0,30 & 0,35 & 0,12 & 0,14 & 0,14 & & & \\
\hline
\end{tabular}

